\title{
THE PREVALENCE OF PHORMIA AZUREA FALLEN (LARVA PARASITIC ON NESTLING BIRDS) IN THE PUGET SOUND REGION AND DATA ON TWO UNDESCRIBED FLIES OF SIMILAR HABIT.
}

\author{
By O. E. Plath.
}

\author{
(Together with Descriptions of the Two New Flies by \\ C. H. T. Townsend and J. M. Aldrich.)
}

In two recent papers ${ }^{1}$ the writer pointed out that the larvæ of Phormia azurea Fallen habitually suck the blood of nestling birds, sometimes with fatal results, and that the adult flies, contrary to the opinion of most dipterists, are quite abundant, at least in the San Francisco Bay Region. Last summer (1918), while visiting Seattle, he had occasion to ascertain whether Phormia azurea Fallen also occurs in the Puget Sound Region and found that it is as frequent there as in the San Francisco Bay Region. During his stay at Seattle (June 15th to August 1st), fifty-four birds' nests were examined containing nestlings belonging to ten different species of birds. Of these fifty-four nests, thirty-three were infested by the larvæ of Phormia azurea Fallen, ${ }^{3}$ one by those of a new species of Phormia, and six by those of a new fly belonging to the genus Hylemyia of the family Anthomyidæ. Drs. J. M. Aldrich and C. H. T. Townsend, of the United States Bureau of Entomology, have been kind enough to describe the two new flies, the descriptions being appended to this paper, and the two flies will hereafter be referred to as

1 Plath, O. E. (a) Parasitism of Nestling Birds by Fly Larvae. The Condor, Vol. XXI (1919), pp. 30-39. (b) A Muscid Larva of the San Francisco Bay Region which Sucks the Blood of Nestling Birds. Univ. Calif. Publ. Zool., Vol. XIX (1919), pp. 191-200.

${ }^{2}$ A synonym of Protocalliphora which Dr. C. H. T. Townsend of the United States Bureau of Entomology considers more appropriate.

${ }^{3}$ A large number of specimens of this fly were sent to Dr. C. H. T. Townsend of the United States Bureau of Entomology who has informed me that the fly was correctly identified by Mr. C. W. Johnson (Cf. a. The Condor, Vol. XXI, p. 34. b. Univ. Calif. Publ. Zool., Vol. XIX, p. 194. Dr. Townsend has also called my attention to the fact that Coutant's fly (Cf. Coutant, A. F., The Habits, Life History, and Structure of a Blood-sucking Muscid Larva (Protocalliphora Azurea). Jour. Parasit., Vol. I, pp. 135-150) is not Protocalliphora (Phormia) azurea Fallen, as was claimed by Coutant, but Phormia chrysorrhea Meigen. This fact, Dr. Townsend thinks, may account for the disparity between Coutant's observations and mine (Cf. The Condor, Vol. XXI, p. 37. b. Univ. Calif. Publ. Zool., Vol. XIX, pp. 198-199). 
Phormia metallica Townsend $\mathrm{d}^{4}$ and Hylemyia nidicola Aldrich. The frequency with which the larvæ of Phormia azurea Fallen were encountered in birds' nests, and the number of larvæ and pupæ per nest, is shown by the following tables:

TABLE I.

\begin{tabular}{|c|c|c|c|c|}
\hline Species of Bird & $\begin{array}{c}\text { Nests } \\
\text { examined }\end{array}$ & $\begin{array}{l}\text { Infested } \\
\text { nests }\end{array}$ & $\begin{array}{l}\text { Uninfested } \\
\text { nests }\end{array}$ & $\begin{array}{l}\text { Infesta- } \\
\text { tion }\end{array}$ \\
\hline $\begin{array}{c}\text { Nuttall Sparrow (Zonotrichia leuco- } \\
\text { phrys nuttalli Ridgway)............ }\end{array}$ & 3 & 3 & 0 & $100 \%$ \\
\hline $\begin{array}{l}\text { Rusty Song Sparrow (Melospiza } \\
\quad \text { melodia morphna Oberholser)....... }\end{array}$ & 2 & 2 & 0 & $100 \%$ \\
\hline $\begin{array}{l}\text { Willow Goldfinch (Astragalinus tris- } \\
\text { tis salicamans (Grinnell)........... }\end{array}$ & 2 & 2 & 0 . & $100 \%$ \\
\hline $\begin{array}{l}\text { Oregon Towhee (Pipilo maculatus } \\
\text { oregonus Bell)................... }\end{array}$ & 1 & 1 & 0 & $100 \%$ \\
\hline 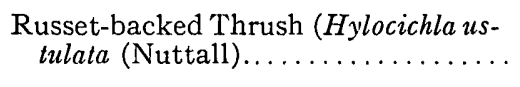 & 5 & 4 & 1 & $80 \%$ \\
\hline $\begin{array}{l}\text { Western Robin (Merula migratoria } \\
\text { propinqua (Ridgway).............. }\end{array}$ & 25 & 18 & 7 & $72 \%$ \\
\hline $\begin{array}{l}\text { Cedar Waxwing (Ampelis cedrorum } \\
\quad(\text { Vieillot }) \ldots \ldots \ldots \ldots \ldots \ldots \ldots \ldots\end{array}$ & 3 & 1 & 2 & $33 \%$ \\
\hline 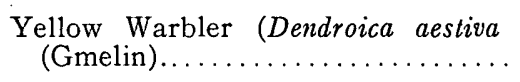 & 5 & 1 & 4 & $20 \%$ \\
\hline 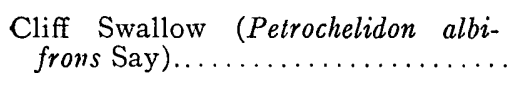 & 7 & 1 & 6 & $14 \%$ \\
\hline $\begin{array}{c}\text { English Sparrow (Passer domesticus } \\
\text { Linnaeus) } \ldots \ldots \ldots \ldots \ldots \ldots \ldots \ldots\end{array}$ & 1 & 0 & 1 & $0 \%$ \\
\hline Totals. & 54 & 33 & 21 & $\begin{array}{c}61 \% \\
\text {;Average }\end{array}$ \\
\hline
\end{tabular}

${ }^{4}$ A species closely related to Phormia chrysorrhea Meigen, the latter, according to Dr. Townsend, being synonymous with Phormia sordida Zetterstedt and Phormia splendida Macquart. 
TABLE II.

\begin{tabular}{|c|c|c|c|}
\hline Species of Bird & $\begin{array}{l}\text { Larvae in Each } \\
\text { Nest }\end{array}$ & Totals & $\begin{array}{l}\text { Larvae } \\
\text { per Nest }\end{array}$ \\
\hline $\begin{array}{c}\text { Nuttall Sparrow (Zonotrichia leuco- } \\
\text { phrys nuttalli Ridgway)............ }\end{array}$ & $39,40,87$. & 166 & 55 \\
\hline $\begin{array}{l}\text { Rusty Song Sparrow (Ifelospiza me- } \\
\text { lodia morphna (Oberholsder)......... }\end{array}$ & $52,55 \ldots$ & 107 & 53 \\
\hline $\begin{array}{l}\text { Cliff Swallow (Petrochelidon albifrons } \\
\text { Say) } \ldots \ldots \ldots \ldots \ldots \ldots \ldots \ldots \ldots \ldots \ldots \ldots \ldots\end{array}$ & $47 \ldots$ & 47 & 47 \\
\hline $\begin{array}{l}\text { Oregon Towhee (Pipilo maculatus } \\
\text { Bell) } \ldots \ldots \ldots \ldots \ldots \ldots \ldots \ldots \ldots \ldots \ldots\end{array}$ & $45 \ldots$ & 45 & 45 \\
\hline $\begin{array}{l}\text { Willow Goldfinch (Astragalinus tris- } \\
\text { tis salicamans (Grinnell)............ }\end{array}$ & $28,59 \ldots \ldots$ & 87 & 43 \\
\hline $\begin{array}{l}\text { Yellow Warbler (Dendroica aestiva } \\
\text { (Gmelin) } \ldots \ldots \ldots \ldots \ldots \ldots \ldots \ldots\end{array}$ & $39 \ldots$ & 39 & 39 \\
\hline 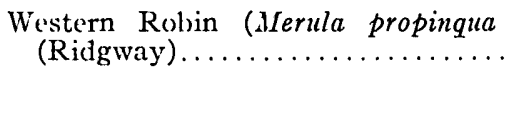 & $\begin{array}{l}7,11,15,16,18,18,21 \\
23,26,27,27,29,37 \\
39,40,43,72,138 \ldots\end{array}$ & 607 & 33 \\
\hline $\begin{array}{l}\text { Russet-backed Thrush (Hylocichla uss- } \\
\text { tulata Nuttall)................... }\end{array}$ & $22,27,28,31 .$. & 108 & 27 \\
\hline $\begin{array}{l}\text { Cedar Waxwing (Ampelis cedrorum } \\
\quad(\text { Vieillot }) \ldots \ldots \ldots \ldots \ldots \ldots \ldots \ldots \ldots \ldots\end{array}$ & 2. & 2 & 2 \\
\hline Totals.. & & 1208 & $\begin{array}{c}36 \\
\text { Average }\end{array}$ \\
\hline
\end{tabular}

All of these nests, excepting eight, were located in shrubs and trees three to twenty feet above ground, while the remaining eight came from an altitude of about forty feet. Seven of the latter (the Cliff Swallow nests) were taken from below the eaves of a two story building on the campus of the University of Washington, and the remaining one (that of the English Sparrow) from a box near the top of a high telephone pole. The comparatively small percentage of infestation of these eight nests might of course be a coincident, but it is perhaps more probable that it was due to the location and structure of the nests.

The thirty-three nests infested by the larvæ of Phormia azurea Fallen contained 111 nestlings. Although many of the larvæ taken from these nests were gorged with blood, only two 
of the 111 nestlings died. That there were no more fatalities is perhaps to be explained by the fact that more than half of the thirty-three infested nests were those of comparatively large birds, the Western Robin and the Oregon Towhee.

The nest infested by the larvæ of Phormia metallica Townsend was that of a Western Robin and contained three nestlings. When the latter took wing, twenty-six larvæ were taken from the nest. The larvæ pupated in a few days and both larvæ and pupæ looked so much like those of Phormia azurea Fallen that the writer was unaware that he was dealing with a new fly until the adults emerged. From the facts at hand it seems probable that Phormia metallica Townsend, both as larva and adult, is similar in habit to that of its near relative, Phormia chrysorrhea Meigen.

The six nests infested by the larvæ of Hylemyia nidicola Aldrich offered an entirely different aspect. When discovered four of them contained the remains (only bones and feathers) of nine, nearly full-fledged nestlings. From these four nests, 283 pupæ were taken nearly all of which later hatched. The remaining two nests infested by the larvæ of Hylemyia nidicola Aldrich were those of a Cliff Swallow and a Yellow Warbler and contained one and five dead nestlings respectively. In these two nests the larvæ were still at their repast. Fifty-nine larvæ were picked from the outer surface of the six dead birds, though many more could undoubtedly have been obtained from within the nestlings. None of the six nests infested by the larvæ of Hylemyia nidicola Aldrich contained any living nestlings when discovered, but judging by the small number of dead birds in most of the nests, it seems possible that some of the nestlings may have survived.

The larva of Hylemyia nidicola Aldrich is much smaller than that of Phormia azurea Fallen and measures about $8 \mathrm{~mm}$. in length and $2 \mathrm{~mm}$. in width when mature. It apparently is not blood-sucking in habit like the larvæ of Phormia azurea Fallen, Phormia chrysorrhea Meigen, and other Muscidæ. The pupa $^{5}$ measures about $5 \mathrm{~mm}$. in length and $2.5 \mathrm{~mm}$. in width and is of a glossy, golden-brown color.

${ }^{5}$ It is identical in size and appearance with the seventy-one secured near Berkeley, California, the preceding summer (Cf. a. The Condor, Vol. XXI, pp. 36-37. b. Univ. Calif. Publ. Zool., Vol. XIX, pp. 196-197). 
There are only two possible explanations in regard to the relation existing between the dead nestlings and the presence of the larvæ of Iylemyia nidicola Aldrich. The first is that the young birds died from some cause or other and that the adult flies were then attracted by the odor of the decomposing nestlings to deposit their eggs, or maggots, on them. The second explanation would be that the eggs, or maggots, were deposited on, or near, the young birds while the latter were still alive, the larvæ subsequently causing the death of the nestlings by penetrating into their body. It has been known for some time that the larvæ of certain species of flies belonging to the genera IIylemyia and Mydaea of the family Anthomyidæ attack nestling birds in Central and South America, ${ }^{6}$ and the second explanation is therefore not an improbable assumption. Should further investigations prove that the larvæ of Hylemyia nidicola Aldrich do attack living nestlings, as now seems probable, then it will be important to determine the range and bring this fly under control if we are not to suffer considerable loss among our wild birds.

As regards subcutaneous parasitism of nestling birds by fly larvæ, I should like to relate an interesting experience I had at Seattle, last summer. During my investigations I came across a nest containing six Willow Goldfinches which were nearly old enough to leave the nest. One of these nestlings had a patch of yellow on its head instead of being of the ordinary color. I turned this bird over to a lady in Seattle to have it reared with a brood of canaries. Two or three days later my attention was called to the fact that some of the feathers on the bird's head were standing up and that the young bird was constantly scratching its head. Upon examining the bird I noticed three small holes, one on top and two at the side of its head. Near the opening of each of these holes the anal end of an active fly larva was visible. The larvæ were extracted with considerable difficulty by means of a pair of scissors and forceps, and were about $5 \mathrm{~mm}$. in length and $2 \mathrm{~mm}$. in width.

${ }^{6}$ Cf. (1) Townsend, C. H. T., (a) The Grass-quit Bot, an Anthomyiid Parasite of Nestling Birds in Jamaica. Jour. Inst. Jamaica, Vol. II, pp. 173-174. (b) Mydaea spermophilae n. sp. (Larva Parasitic on Nestling Birds). Trans. Amer. Ent. Soc., Vol. XXII, p. 79. (2) Nielsen, J. C., (a) Mydaea anomala Jaenn., a Parasite of South-American Birds. Vidensk. Meddel. fra Dansk Naturhist. Foren. Bd. 63 (1912), pp. 195-208. (b) On Some South-American Species of the Genus Mydaea, Parasitic on Birds, ibid. Bd. 65 (1913), pp. 251-256. 
They were similar in appearance to the immature larvæ of Phormia azurea Fallen, but showed no blood in their intestines. I tried to rear these three larvæ, but all three died before pupating. The young goldfinch completely recovered from the rather severe operation and is still living (March, 1919).

The study of birds' nests from the viewpoint of the entomologist and parasitologist seems thus far to have been rather neglected. While examining Cliff Swallow nests below the eaves of a two-story building on the campus of the University of Washington, I found them so thickly infested by bed bugs ${ }^{7}$ that I preferred to leave the remaining nests alone. Another blood-sucking insect that seems to use birds' nests as a favorable breeding place is the flea. I had encountered numerous flea larvæ in birds' nests near Berkeley, California, the preceding summer (1917), but when I saw the almost increditable multitude of flea larvæ contained in a single sparrow nest which was taken from a box near the top of a high telephone pole at Seattle, I was amazed. In addition to the parasites which I have spoken of as inhabiting birds' nests, two or three others were mentioned in one of my recent papers, ${ }^{8}$ and this number will undoubtedly be increased. These facts make it evident that birds' nests offer a fruitful field of investigation for the professional parasitologist.

${ }^{7}$ Very probably Oecacus (Acanthia) hirundinis Jen., a species closely related to the common bed bug, Cimex (Acanthia) lectularia Linnaeus, but more slender than the latter.

${ }^{8}$ Cf. The Condor, Vol. XXI, pp. 35-36. 


\title{
Description of the New Species of Phormia.
}

\author{
By C. H. T. Townsend, \\ United States Bureau of Entomology, Washington, D. C.
}

\section{Phormia metallica n. sp.}

Length, 7 to $8.5 \mathrm{~mm}$. Twenty-eight specimens, all females; eight pinned from New Hampshire, Virginia, Illinois, Wisconsin; and twenty, of which ten are alcoholic, from Puget Sound, Washington State, reared by Mr. O. E. Plath from maggots taken from nests containing young birds.

Female vertex one-sixth to one-fourth head width. Head brownish, thinly olive-grayish pollinose, with more or less of a brassy tinge. Viewed obliquely from below the whole face appears blackish, with a conspicuous golden spot at upper end of both parafacilia. Antennæ wholly blackish or brown, the third joint one and one-half to two times as long as second. Palpi fulvous to rufous, the tips fuscous. Thorax and scutellum dark metallic greenish-black to bright cupreous or brassygreen, silvery to olive-gray pollinose, leaving three nearly equal and rather heavy vittæ of the ground color. There is a faint narrow dark vitta barely visible in front close on each side of the median vitta in some specimens. Abdomen metallic dark bluish-green to bright cupreous or golden-green, showing thin silvery pollen coat in certain lights, the anal segment always cupreous to golden-green. Legs blackish. Wings clear. Tegulæ white to buff-yellow.

Holotype from Franconia, New Hampshire.

There is a well marked difference in the two forms here described as one species. The typical form, represented from all the above localities, is the darker one, with only the anal segment golden-green, and the tegulæ white. The vertex is about or nearly one-fourth head width, and the length is 7 to $8.5 \mathrm{~mm}$. Thoracic pollen silvery.

The other form, represented by three New Hampshire and four Puget Sound specimens, has the abdomen wholly cupreous to golden-green, the anal segment being concolorous; the thorax and scutellum cupreous to brassy-green, almost the same shade as abdomen; and the tegulæ deep buff-yellow. This form will perhaps prove to be a good subspecies, or it may even be specifically distinct. The front is narrower in this form, the vertex running from one-sixth to little over one-fifth head width, and the length is 7 to $7.75 \mathrm{~mm}$. Thoracic pollen olive-gray.

The Puget Sound specimens; of both forms, have the third antennal joint about twice as long as second, the second joint 
being moderately short. The eastern specimens, of both forms, have the second antennal joint longer, and the third joint only about one and one-half times as long as second.

The typical form was identified by Coquillett as Calliphora splendida Macquart, and specimens of the other form were included in the series so labeled by him. Macquart's specimen was from Galveston, Texas, and the size was given as five lines or $10 \mathrm{~mm}$. The thorax and scutellum were stated to be black, the abdomen greenish-blue with tip golden. The first two antennal joints were said to be very short, and testaceous in color. Also the wings were said to be fuscous on costal border. On account of these discrepancies, I am unable to identify the present forms as Macquart's species, which appears certainly to be a synonym of chrysorrhea Meigen.

\section{Description of a New Species of Hylemyia.}

\section{By J. M. Aldrich,}

United States Bureau of Entomology, Washington, D. C.

\section{Hylemyia nidicola n. $\mathrm{sp}$.}

Male-Deep black, with yellow halteres; calypters infuscated, almost black, with the fringe dark'below.

Front hardly wider than lower ocellus; six pairs of frontal bristles, beginning at middle; frontal and facial orbits dark, not silvery, narrow; antennæ black, rather large, third joint reaching nearly to edge of mouth, twice as long as second, arista bare; face flat, edge of mouth very little protruding; bucca about one-eighth the eye-height, rather bristly; palpi and proboscis black, ordinary; back of head flat, with coarse black hair.

Thorax deep black, rather velvety above, with a trace of paler pollen at inner edge of humerus each side; two to three pairs of large anterior acrostichals, three posterior dorsocentrals, three sternopleurals; metanotum with gray pollen; pteropleura and hypopleura without hairs.

Abdomen black, with a faint, interrupted lighter pollinose crossband on each segment and a median dark stripe; fifth sternite with deep excision and two long black lobes, which do not bear any striking bristles.

Genitalia rather small; first genital segment shining black, with about twenty small bristles; second segment subshining, with ordinary hairs directed backward; inner forceps united, short, beadlike, with two long hairs on each side near tip; outer forceps dark brown, shining, twisted, not long, rounded at tip.

Legs wholly black, without striking characters, pulvilli a little enlarged, brownish; front tibia with one or two bristles on outer hind 